\title{
«POR LAS HUELGAS LOS JUGLARES». ALFONSO XI DE COMPOSTELA A BURGOS, SIGUIENDO EL LIBRO DE LA CORONACIÓN \\ DE LOS REYES DE CASTILLA
}

\author{
Eduardo Carrero Santamaría \\ Universitat Autònoma de Barcelona \\ Eduardo.Carrero@uab.cat
}

\begin{abstract}
Resum
El Libro de la Coronación de los Reyes de Castilla (Real Biblioteca de El Escorial, Cód. \& III-3) es un códice que reúne dos ordines de coronación pertenecientes, respectivamente, a los reyes de Castilla y de Aragón. El primero fue preparado para la coronación y unción de Alfonso XI de Castilla, que tuvo lugar en I332, tratándose de la única pieza conservada de similares características para un rey de Castilla. Recogiendo una interesada adaptación del Ordo de coronación imperial, llamado de Constantinopla, quedó inacabado en texto y miniatura, tras la ceremonia de toma de armas.
\end{abstract}

\section{Paraules clau}

Coronación, liturgia, toma de armas, autómata, Santiago de Compostela, Las Huelgas, Burgos, miniatura.

\begin{abstract}
The Libro de la Coronación de los Reyes de Castilla (Real Biblioteca de El Escorial, Cód. $\&$ III-3) is an extraordinary manuscript that combines two fourteenth-century coronation ordines of the kings of Castile and Aragon. The first was seemingly prepared for the coronation and anointing of Alfonso XI of Castile, an event that eventually took place in 1332. It is the only such liturgical codex preserved for a Castilian king. The text adapts an imperial coronation Ordo, the so-called Ordo of Constantinople. The text remained unfinished after the description of the ceremony of the king's taking up of arms.
\end{abstract}

\section{Keywords}

Coronation, liturgy, knighting, anointing, automata, Santiago de Compostela, Las Huelgas, Burgos, illumination. 
Nunca un rey de Castilla tuvo un conjunto de noticias y descripciones tan ricas sobre su coronación. La tradicionalmente parca en detalles historiografía castellana hizo aquí una excepción. En 1332 el rey era coronado en Las Huelgas de Burgos tras una terrible minoría de edad marcada por la regencia de su abuela María de Molina y los problemas con la nobleza castellana y la aspiración al trono por varios de los segundones de la corte. Es evidente que en la ceremonia y en la propia descripción de la misma influyeron todos estos hechos. Alfonso XI era el hijo de Fernando Iv de Castilla y Beatriz de Portugal que, a su vez, fue el hijo del tremendo Sancho iv y la aún más fascinante María de Molina. La minoría de Fernando a la muerte de Sancho hizo reinar a María quien tuvo que volver a tomar las riendas de la corona castellana tras la inesperada muerte de Fernando en I3I2, y a la espera de la mayoría de edad de Alfonso XI. En tan sólo veintiséis años, María de Molina se encargó de defender los derechos dinásticos de su marido Sancho IV en dos ocasiones, con su propio hijo considerado ilegítimo (I295-I30I) y con su nieto (I3I2-I32I), siempre en un convulso período histórico para los reinos de la Península, gobernados en el lapso cronológico por Jaime II (I267-I327) y Blanca de Anjou en Aragón, Dinís (I26I-I325) e Isabel de Aragón en Portugal y la terrible sucesión de seis capetos en algo más de cincuenta años en el trono de Navarra. María de Molina se reveló como una hábil estratega y es que a la fuerza ahorcan. La situación política en Castilla le obligaba a buscar apoyos en las restantes casas reales peninsulares y establecer una serie de contactos políticos que tendrían su consiguiente reflejo en la cultura regia de la época.

Pero volvamos a la liturgia real. Como decía, en 1332 Alfonso se coronaba en Las Huelgas. La ceremonia había venido precedida por la toma de armas en la catedral de Santiago, un paisaje arquitectónico e institucional lo suficientemente elocuente: la tumba del Apóstol y uno de los monasterios clave en el imaginario de la corona castellana. Contamos con tres fuentes diferentes relacionadas con la coronación burgalesa de Alfonso XI. En primer lugar su crónica, en donde encontramos uno de los relatos más atractivos del acontecimiento, en donde se describe pormenorizadamente cómo fueron los festejos que rodearon al acto y la propia ceremonia litúrgica. ${ }^{I}$ En segundo, el Poema de Alfonso XI, encargo real al poeta Ruy Yáñez y que constituye una de las piezas literarias más fascinantes sobre la loa y ensalzamiento de un rey peninsular en vida. El capítulo dedicado a la coronación es una descripción fascinante de carrozas que asemejaban barcos que navegaban por tierra y de bailarinas, poetas y juglares que bailaban, declamaban y tañían sus instrumentos por el monasterio. ${ }^{2}$ Por último, desde que Claudio Sán-

I Crónicas de los Reyes de Castilla, desde don Alfonso el Sabio hasta los Católicos don Fernando y doña Isabel, ed. C. RoselL, 3 vols., Madrid, I898, I, pp. I332-35.

2 Poema de Alfonso Onceno, ed. J. Victorio, Madrid, I99I, pp. II9-24. 
chez Albornoz realizara la edición de su texto, también se atribuye al hecho histórico de la coronación el único ceremonial de estas características que conservamos en Castilla, el llamado Libro de la Coronación, hoy conservado en la Biblioteca del Monasterio de El Escorial. Se trata de un códice complejo, compuesto por dos ordines diferentes, uno de los reyes de Castilla y otro de los reyes de Aragón que fueron cosidos en un mismo volumen, sin que tengamos muy claro el por qué. ${ }^{3}$

Si el texto aragonés fue estudiado por Salvá y Sáinz de Baranda primero y Bonifacio Palacios después y es perfectamente acorde a la situación de la monarquía aragonesa en el siglo xiv, el castellano presenta más complicaciones de lo que a primera vista pudiera parecer. ${ }^{4}$ Está integrado por un ceremonial de coronación firmado por un tal Ramón, obispo de Coimbra, con una introducción teórica y el propio texto litúrgico compuesto por oraciones y rúbricas describiendo el ceremonial, adaptado de un Ordo de coronación imperial.5 Para más detalle, cada acto de cierta importancia está ilustrado por una miniatura generalmente a folio completo - en total de 2I- y una glosa de su contenido a modo de pie de foto. Llamemos la atención sobre una circunstancia básica: a partir de la imagen ocho todas se encuentran inacabadas y las tres últimas, represendo un grupo de gente y mesas preparadas para un banquete son las únicas que no tienen indicaciones textuales sobre su significado ni relación alguna con el texto, quizás manco de una proyectada descripción de las celebraciones posteriores a la coronación. Desde un punto de vista estilístico, las imágenes han sido relacionadas con la miniatura francesa de comienzos del siglo xIV, mientras que los fondos neutros refieren posibles influencias inglesas. ${ }^{6}$ Evidentemente nos encontramos ante un manual,

3 C. Sánchez-Albornoz, "Un ceremonial inédito de coronación de los Reyes de Castilla", Logos, 2 (1943), pp. 75-97, reed. en Viejos y nuevos estudios sobre instituciones medievales españolas, 3 vols. Madrid, I976-80, II, pp. I209-36.

4 Publicado en M. Salvá y P. Sárnz de Baranda, Colección de documentos inéditos para la historia de España, Xiv, Madrid, I894, pp. 556-68; B. Palacios Martín, La coronación de los Reyes de Aragón (I204-I4IO). Aportación al estudio de las estructuras medievales, Valencia, 1975, pp. 232-40. Sobre el ceremonial aragonés y su contexto, véanse Palacios Martín, "El ceremonial", en Ceremonial de Consagración y Coronación de los Reyes de Aragón, ms. R.I4.425 de la Biblioteca de la Fundación Lázaro Galdiano, en Madrid, Zaragoza, 1992, pp. I03-33, y "Estudio", en El Manuscrito de San Miguel de los Reyes de las "Ordenacions" de Pedro IV, 2 vols., Valencia, 1994, I, pp. 9-87.

5 En I950, Percy E. Schramm atribuyó el manuscrito a Raimundo de Losana, Arzobispo de Sevilla, asunto que Sánchez Albornoz se ocupó de aclarar: E. Costa y Belda, "Las constituciones de don Raimundo de Losana para el Cabildo de Sevilla (I26I)", Historia. Instituciones. Documentos, 5 (1978), pp. I69-233.

6 Véanse J. Domínguez Bordona, Exposición de códices miniados españoles, Madrid, 1929, pp. 90-9I, J. YARZa Luaces, "Libro de la Coronación", en Vestiduras ricas. El monasterio de Las Huelgas y su época II70-I340, Madrid, 2005, pp. I5I-53, O. Pérez Monzón, "Libro de la Coronación de los Reyes de Castilla y Aragón”, en Maravillas de la España medieval. Tesoro sagrado y monarquía, coord. I. G. BANGO, 2 vols., Madrid, 2000, I, pp. 97-98, e ID., "Ceremonias regias en la Castilla medieval. 
un volumen para ser usado por un maestro de ceremonias, un chantre catedralicio quizás, en un lugar donde actos como éste no debían ser demasiado habituales. De hecho, se ha insistido en la escasez de ceremoniales e imágenes de coronaciones para Castilla, subrayando el escaso interés de la monarquía castellana en la consideración sacra que el rito reclamaba. ${ }^{7}$ Por lo tanto, este presumible y por tanto proyectado aspecto funcional del códice escurialense lo aleja de la propuesta de Paul Binski para el Liber Regalis, según la cual los ceremoniales de coronación no tuvieron un objetivo funcional, sino que se trató de libros de lujo, a menudo concebidos como regalo y piezas de prestigio. ${ }^{8}$

\section{Problemas del Ceremonial}

Tras la edición del texto por Claudio Sánchez Albornoz a mediados del siglo xx, el códice ha sido utilizado con interpretaciones claramente opuestas en trabajos de teoría política sobre la monarquía castellana. Presente en distintas exposiciones por sus miniaturas, lo cierto es que no ha terminado de motivar la monografía de enjundia que merecería. ${ }^{9}$ Junto a su importancia histórica y artística, el

A propósito del llamado Libro de la Coronación de los Reyes de Castilla y Aragón”, Archivo Español de Arte, 332 (2010), pp. 317-34.

7 T. F. Ruiz, "Une royauté sans sacre: la monarchie castillaine du Bas Moyen Âge", Annales ESC, 39 (1984), pp. 429-53; P. Linehan, "Ideología y liturgia durante el reinado de Alfonso xi”, en Génesis medieval del estado moderno: Castilla y Navarra (I250-1370), ed. A. RucQuor, Valladolid, I987, pp. 229-43; P. Linehan, "Pseudo-historia y pseudo-liturgia en la obra alfonsina", en España y Europa. Un pasado jurídico común, ed. by A. Pérez Martín, Murcia, 1986, pp. 259-74.

8 P. Binski, "The Liber Regalis: Its Date and European Context", en The Real Image of Richard II and the Wilton Diptych, eds. D. Gordon, L. Monna y C. Elam, Londres, 1997, pp. 233-46. En comparación con los ceremoniales de coronación ilustrados en Francia, véase A. D. Hedeman, "The Commemoration of Jeanne d"Evreux"s Coronation in the Ordo ad Consecrandum at the University of Illinois", Essays in Medieval Studies: Proceedings of the Illinois Medieval Association, 7 (1990), pp. 13-28; Le sacre royal à l'époque de Saint-Louis: d“après le manuscrit latin I246 de la BNF, ed. J. Le Goff, París, 200I.

9 La bibliografía correspondiente en F. María Tubino y Rada, "Códice de la Coronación. Manuscrito en pergamino del siglo XIv, con miniaturas, perteneciente a la Biblioteca del Monasterio de San Lorenzo del Escorial”, Museo Español de Antigüedades, 5 (I875), p. 48; J. Zarco Cuevas, Catálogo de los manuscritos castellanos de la Real Biblioteca de El Escorial, 3 vols., Madrid-San Lorenzo de El Escorial, I924-I929, III, Índices y apéndices, pp. 43I-33; J. Domínguez Bordona, Miniatura, Ars Hispaniae XVIII, Madrid, I962, p. I30; P. Ramos Vicent, "Reafirmación del poder monárquico en Castilla: la coronación de Alfonso xI", Cuadernos de Historia Medieval, 3 (1983), pp. 5-36; P. LineHan, History and the Historians of Medieval Spain, Oxford, 1993 [edición castellana, Salamanca, 20I2], pp. 584-6oi; J. Manuel Nieto Soria, "Los libros de ceremoniales regios en Castilla y Aragón en el siglo XIv", en El ceremonial de coronación, unción y exequias de los reyes de Inglaterra del Archivo General de Pamplona, vol. II, Estudios, ed. E. Ramírez Vaquero, Pamplona, 2008, pp. 177-94; 
códice es también importante para la historia de la música, incluyendo la notación musical para las piezas que se habrían escuchado durante la coronación del rey de Castilla. Un estudio de la misma podría permitirnos ahondar aún más en nuestra comprensión del proyecto ceremonial, contemplando en la medida de lo posible cómo habría sonado el ritual. ${ }^{\mathrm{IO}}$ Hoy en día, nuestro códice sigue siendo una fuente básica pero que plantea tantos problemas como posibilidades. De hecho, y por poner un ejemplo claro y conciso, suele considerarse que nuestro libro se trata de la más depurada descripción de la ceremonia de coronación de Alfonso XI que tuvo lugar en Las Huelgas en I332. Por el contrario, lo primero que llama la atención al lector es que nada más comenzar el relato del ceremonial tras una interesante introducción, el liturgista encargado ya nos avisa de que el acto tendría lugar en la ciudad de Santiago de Compostela y, en particular, en su catedral. El problema sobre la generalizada confusión de lugar entre lo prescrito en el códice y el acontecimiento real vuelve a remitirnos a su edición textual por Claudio Sánchez Albornoz en 1943, sobre un texto original de una conferencia impartida en 1913. El historiador abulense se enfrentó a dos cuestiones claves para su interpretación: la primera que se encontraba ante el único ceremonial de estas características adscrito a la monarquía castellana. La segunda que, a pesar de su denodado intento por restar importancia al asunto de la mejor manera que pudo, las noticias sobre coronaciones en los reinos de Castilla y León son dispersas y en buena parte de las ocasiones de difícil explicación. Nada más fácil que vincular el ceremonial conservado en El Escorial con la única gran coronación descrita por los cronistas de Castilla. Así parecía además refrendarlo la cronología del códice, cuya caligrafía, música y miniatura nos dirigen indudablemente hacia el siglo XIV. ${ }^{\text {II }}$ Una gran coronación, un texto que la describe, la urdimbre del tapiz parecía ya tejida.

Pérez Monzón, "Libro de la Coronación“; Yarza Luaces, "Libro de la Coronación”, pp. I5I-53; y Pérez Monzón, "Ceremonias regias en la Castilla medieval".

Io Algunos estudios sobre la coronación real francesa en Reims hacia I200 insisten en esta misma cuestión, aunque desde una perspectiva antropológica: E. Henrik Aubert, "O som e seus sentidos no Ordo ad consecrandum regem (c. I250)", Bulletin du centre d"études médiévales d"Auxerre BUCEMA, Hors série 2 (2008), Le Moyen Âge vu d'ailleurs, en línea [consultado 02.01.2012]: $<$ http://cem.revues.org/index9382.html>, y la versión completa de sus argumentos en "Le son et ses sens. L'Ordo ad consecrandum et coronandum regem (v. I250)", Annales. Histoire, Sciences Sociales, 62-2 (2007), pp. 387-4II. La música de nuestro códice has sido analizada por Ismael Fernández de la Cuesta, "El Libro de la Coronación de Reyes del Escorial (Homenaje a Robert Stevenson)", Nassarre. Revista aragonesa de musicología, IO-I (1994), pp. 6I-96.

II Sería interesante adaptar a la miniatura las vías de aproximación propuestas para la escultura por R. SÁnchez Ameijeiras, "Crisis, ¿qué crisis? Sobre la escultura castellana de la primera mitad del siglo XIV", en El "Trecento" en obres. Art de Catalunya i art d"Europa al segle XIV, ed. R. Alcoy, Barcelona, 2009, pp. 243-72. 
Un análisis de la pieza con mayor detalle nos conduce a reconsiderar la naturaleza de su relación con la efectiva coronación de Alfonso XI. La primera, como citaba hace unos momentos, que el códice se redactara para un acto litúrgico en Santiago de Compostela y que, en realidad, éste tuviera lugar en Burgos. Distintos autores han querido justificarlo a través de un cambio de parecer en los itinerarios reales que llevó a realizar la ceremonia en Burgos, o mediante la efectiva celebración de la toma de armas del rey en Santiago la semana ante de la coronación y que habría producido una confusión general entre una y otra ceremonia. Personalmente, me parece demasiada precariedad para un acto solemne de los que no se realizaban en Castilla y que implicaba una movilización de gentes y realización de preparativos de cierta importancia. Una pregunta se impone, ¿iba a redactarse un ceremonial de coronación real e ilustrarse con miniaturas, implicando directamente a la catedral de Santiago de Compostela que aparece fielmente retratada en el mismo, como tendremos ocasión de ver, para después cambiar de opinión y llevarse la ceremonia a Burgos? Muy posiblemente la prosapia regia en los ceremoniales regios de la propia catedral de Santiago y la conexión portuguesa que incluía al arzobispo compostelano don Berenguel de Landoira entre la corte que rodeaba a María de Molina durante la regencia fueron los que pudieron hacer prevalecer una primera intención que, a la postre, quedaría reducida a una toma de armas lacónicamente referida en las fuentes, para llevar la gran ceremonia de coronación a Burgos. ${ }^{12}$

\section{La catedral de Santiago}

Planteados estos problemas, pasemos entonces al propio ceremonial en la catedral de Santiago y al análisis del escenario arquitectónico que relata nuestro texto. La trasposición de ceremonias desde Roma a Santiago de Compostela y desde San Pedro a la catedral sugiere que el autor de nuestro códice adaptó el Ordo imperial en el que se basa a un lugar que le resultaba familiar. Siguiendo el texto y sus ilustraciones podemos reconstruir algunos espacios de la ciudad y la propia catedral y, sobre todo, seguir las circulaciones de la ceremonia y sus participantes por el interior del edificio, y constatar la composición de altares y otras instalaciones litúrgicas durante el desarrollo del ceremonial.

De acuerdo con el texto, el rey, la reina y su cortejo se dirigían hacia la ciudad, a cuyas puertas les esperaba la aristocracia eclesiástica. La procesión iba compuesta

i2 E. Carrero Santamaría, "Architecture and Liturgical Space in the Cathedral of Santiago de Compostela. The Libro de la Coronación de los Reyes de Castilla", Hispanic Research Journal, I3/5 (2012), pp. 466-86. 
por los personajes que llevaban las armas reales y lanzaban monedas entre los asistentes precediendo a los reyes. [Fig. I] El clero llegaba a la catedral y entraba en ella, mientras el séquito real esperaba en la puerta. Allí regresaba a recoger al rey el arzobispo de Santiago, quien acompañaba al rey desde la puerta de la catedral hasta una capilla de la girola, donde el monarca se revestía con las ropas con las enseńas reales. [Fig. 2] El clero regresaba a la puerta de la catedral, donde esperaba la reina, que rezaba una oración al entrar en el templo. Después y al igual que el rey, era trasladada a una capilla de la girola de la catedral — muy posiblemente la opuesta al rey- donde también se revestía con las enseñas reales. El rey era llevado primero al altar de Santiago, interesante en tanto que era dirigido hacia la parte más importante de la catedral, donde se reverenciaban las reliquias del Apóstol sobre las que se construyó el altar mayor, [Fig. 3] en clara analogía entre la confessio definida por la Historia Compostellana en el altar de la catedral y la confessionem beate Petri indicada en el Ordo de coronación imperial. ${ }^{13}$

Tras esto, el rey y la reina se echaban a rezar frente al altar-relicario, momento previo al instante álgido de la unción real. Aquí, el ceremonial describe cómo el monarca era trasladado a una capilla cercana al altar mayor donde era ungido. [Figs. 4 y 5 ] ¿Cuál es la capilla en la que se ungió al rey y a la reina? Este espacio no debió ser otro que la retrocapilla que hacía las funciones de receptora de peregrinos a espaldas del altar mayor y lugar de celebración de las misas matinales del Apóstol en su altar de la Magdalena —ubi decantantur misse matutinales peregrinis, según el Calixtino-, ahora convertido en marco escenográfico regio. ${ }^{14}$

Tras la unción, los monarcas eran trasladados hasta unos estrados elevados a tal efecto en el interior de la catedral

Et los ordenadores de la corte seyan nombrados e fagan façer un sobrado que se llama balcón dentro en la yglesia. Et que seya tan grande que pueda y caber el estrado del Rey a la parte derecha e él con sus ricos ommes e con sus caualleros. Et a la parte esquierda el estrado de la Reyna e ella con sus duennas e con sus donçellas. ${ }^{15}$ [Fig. 6]

El estrado o balcó $f$ n estaba localizado según el códice "sobre la puerta principal de la catedral”, y ésta no era otra que el Pórtico de la Gloria. Y es que el Pórtico no era sólo la entrada a la catedral. Como Rocío Sánchez Ameijeiras ha indicado, también se trataba de un lugar regio, con imágenes y significados reales ${ }^{16}$. Además,

I3 R. Elze, Die Ordines für die Weihe und Krönung des Kaisers und der Kaiserin, Hannover, 1960, p. 53.

I4 E. Carrero Santamaría, "Le sanctuaire de la cathédrale de Saint-Jacques-de-Compostelle à l'épreuve de la liturgie", en Saint-Martial de Limoges. Ambition politique et production culturelle ( $X^{e}$ XIII siècles), ed. C. Andrault-Schmitt, Limoges, 2006, pp. 295-308.

I5 SÁnchez Albornoz, "Un ceremonial inédito...”, p. I244.

I6 R. SÁnchez Ameijeiras, "El entorno imaginario del rey: cultura cortesana y/o cultura clerical 
la colocación de los estrados reales tendría un radical problema de visibilidad como era la presencia del coro tardorrománico que se situaba en medio de la nave y que, obligatoriamente, limitaría en la visualización del altar mayor donde se iba a celebrar la misa de la coronación. ${ }^{17}$ De aquí que el ceremonial insista en la grandiosidad de los estrados en los que se subieron el rey y la reina con sus hombres y damas de corte. El miniaturista, del mismo modo, representó los altos estrados que debían salvar el coro y permitir contemplar la ceremonia litúrgica. ${ }^{18}$ Mientras, el ceremonial de coronación recoge uno de los momentos más interesantes del acontecimiento, como es el canto, baile y tañido de panderos por un hombre y algunas mujeres en el interior de la catedral. ${ }^{19}$ [Fig. 7]

Para finalizar, al terminar los oficios, el rey regresaba a la capilla mayor de cuyo altar recogía la espada que le reconocía como caballero. El juramento se realizaba frente a la figura del Apóstol que desde el siglo XIII preside el altar mayor de la catedral compostelana y que era objeto de una paraliturgia de peregrinos. Efectivamente, esta es la única cuestión que ocurrió realmente. Como aludimos líneas atrás, el rey sí se armó caballero en la catedral de Santiago y, según la propia crónica,

tomando él por si mesmo todas las armas del altar de Sanctiago, que ge las non dio otro ninguno: et la imagen de Sanctiago, que estaban encima del altar, llegóse el Rey a ella, et fízole que le diese la pescozada en el carriello. ${ }^{20}$

No sabemos a qué tipo de actos simbólico alude esta descripción, ya que la imagen compostelana difícilmente puede dar una bofetada a nadie. Nada que ver esta imagen con la que la a veces calenturienta óptica moderna y contemporánea

en Galicia en tiempos de Alfonso XI", en Alfonso IX y su época. Pro Utilitate Regni mei, La Coruña, 2008, pp. 307-326, e ID., "Archetypical and Actual Buildings and Kings: Galician imagery (II53I230)?”, en Culture and Society in Medieval Galicia, ed. J. D’Emilio y D. Mackenzie, Leiden, en prensa.

I7 Sobre la sillería tardorrománica y su localización en la topografía catedralicia, véase E. CARRERO Santamaría, "Centro y periferia en la ordenación de espacios litúrgicos: las estructuras corales", Hortus Artium Medivalium, I4 (2008), I59-79, y "Presbiterio y coro en la catedral de Toledo. En busca de unas circunstancias", Hortus Artium Medievalium, I5-2 (2009), 315-27.

I8 Las tribunas de madera proyectadas para Compostela son muy diferentes de los púlpitos que se colocaron en los transeptos de Reims y Westminster durante las coronaciones de los reyes de Francia e Inglaterra. Véase P. BINsKi, Westmister Abbey and the Plantagenets. Kingship and the Representation of Power I200-I400, Londres-New Haven, 1995, p. I31.

I9 Sobre su interpretación I. Fernández de LA Cuesta, "El baile en la iglesia: la rúbrica sobre la danza en el Ceremonial de Coronación de los Reyes de la Biblioteca del Escorial”, en Música en el Monasterio del Escorial: Actas del Simposium (I,4-IX-I992), ed. F. J. CAmpos, San Lorenzo del Escorial, I993, pp. 323-4I, y M. Gómez Muntané, La música medieval en España, Zaragoza, 200I, p. IOI. 20 Crónicas de los Reyes de Castilla, p. 234. 
nos ha dejado del asunto a través de una talla bien conocida. Una de las más sorprendentes imágenes y tradiciones que nos haya legado la historia de Castilla es la del supuesto autómata del Apóstol que, custodiado por las monjas cistercienses, pasó a cargar sobre sus hombros la leyenda de su supuesto uso como intermediario entre Dios y el rey. [Fig. 8] Se trata de una imagen datada en la primera mitad del siglo XIV y en la que algunos investigadores han querido identificar con la que según la Crónica real habría sancionado la caballería del rey en Compostela y después habría sido trasladada a Las Huelgas. ${ }^{2 \mathrm{I}}$ De este modo, la imagen habría servido para dar el espaldarazo al monarca durante su toma de armas sin la intervención de más mano humana que la de aquél encargado de accionar un tosco mecanismo de elevación del brazo que alzaría la espada sobre el hombro real, sin intervención eclesiástica alguna y haciendo intervenir directamente la mano divina en lugar de la habitual ceremonia de "autoinvestidura" de los monarcas castellanos, definida por Bonifacio Palacios. ${ }^{22}$ Una historia demasiado absurda incluso para los siglos XII y xIV. Si algunos investigadores cuestionamos su realidad, la restauración de la talla hace unos ańos reveló que se trata en realidad de una imagen de la Virgen que, en un momento indeterminado, fue transformada en Santiago con una barba postiza, muy posiblemente inspirada en el texto de la crónica que citábamos. ${ }^{23}$ Por otro lado, el dispositivo al que en alguna ocasión se ha aludido y que haría moverse los brazos de la imagen no es más que la simple articulación de éstos a la altura de los hombros con unos brazos de indudable factura moderna. En mi opinión, no hay lugar a duda de que la figura no tuvo que ver con la monarquía castellana más allá de lo que las propias monjas pudieran estimar. Es más, podríamos proponer que en realidad la pieza no fuera más que una de las que sabemos bien se utilizaban en las representaciones teatrales que solían realizarse en los monasterios de puertas adentro ¿Motivada tal vez por la sanción papal a la monarquía castellana con la canonización de Fernando III en I671? Quién sabe. La leyenda real alrededor de Las Huelgas y, lo que es aún peor, la comodidad del lugar común historiográfico han llevado a varios historiadores hasta hoy en día a situar a nuestra Virgen travestida en Apóstol en el escenario

2I Véase P. Linehan, "Alfonso XI of Castile and the Arm of Santiago (with a note on the Pope"s Foot)", en Miscellanea Domenico Maffei dicata. Historia-Ius-Studium, ed. A. García Y García y P. Weimar, Frankfurt, 1995, pp. I2I-46, repr. en The Processes of Politics and the Rule of Law. Studies on the Iberian Kingdoms and Papal Rome in the Middle Ages, Aldershot, 2002, s.p.

22 Palacios Martín, "Investidura de armas", pp. I85-9i.

23 Algunas notas al respecto en E. Carrero Santamaría, "Observaciones sobre la topografía sacra y cementerial de Santa María la Real de las Huelgas, en Burgos, y su materialización arquitectónica", in La clausura femenina en España. Actas del Simposium, 2 vols., San Lorenzo del Escorial, 2004, II, pp. 695-715. Una corta reseña del restaurador en F. Torrón Durán, "Imagen de Santiago del espaldarazo en Las Huelgas de Burgos”, Abrente, 38-39 (2006-2007), pp. 73-74. 
de las celebraciones reales entorno Las Huelgas e, incluso como decía, a traerla y llevarla desde Burgos a Compostela y viceversa como una pieza de atrezo más en la liturgia real.

De Santiago a las Huelgas. El escenario real

Para finalizar, ¿qué ocurrió finalmente con la coronación de Alfonso XI en I332? ¿Tuvo algo que ver con el ceremonial descrito para Santiago en el códice de El Escorial? Sí y no. Por un lado, el rey tomó las armas en Compostela y no en Las Huelgas, lugar para el que dejó la coronación propiamente dicha. Por lo demás, el relato de la coronación es prácticamente el mismo, cambiando la ciudad de Compostela por la de Burgos y la catedral de Santiago por el monasterio de Las Huelgas. Se describen la procesión caballeresca desde Burgos a Las Huelgas y los ritos de puesta de las espuelas, la presencia de un buen número de los prelados de sus reinos, los altos estrados cubiertos de telas para instalar al rey y la reina, la colocación de los personajes en el profundo presbiterio de la iglesia y, sobre todo, los actos festivos que roderon a la ceremonia, explícitamente detallados en el Poema del rey. En fin, paso a paso el ritual preparado, pensado y redactado para la coronación de un monarca, en una tierra en la que escaseaban solemnidades afines y que sólo cambió el escenario de la celebración de la catedral del Apóstol al monasterio del rey. 


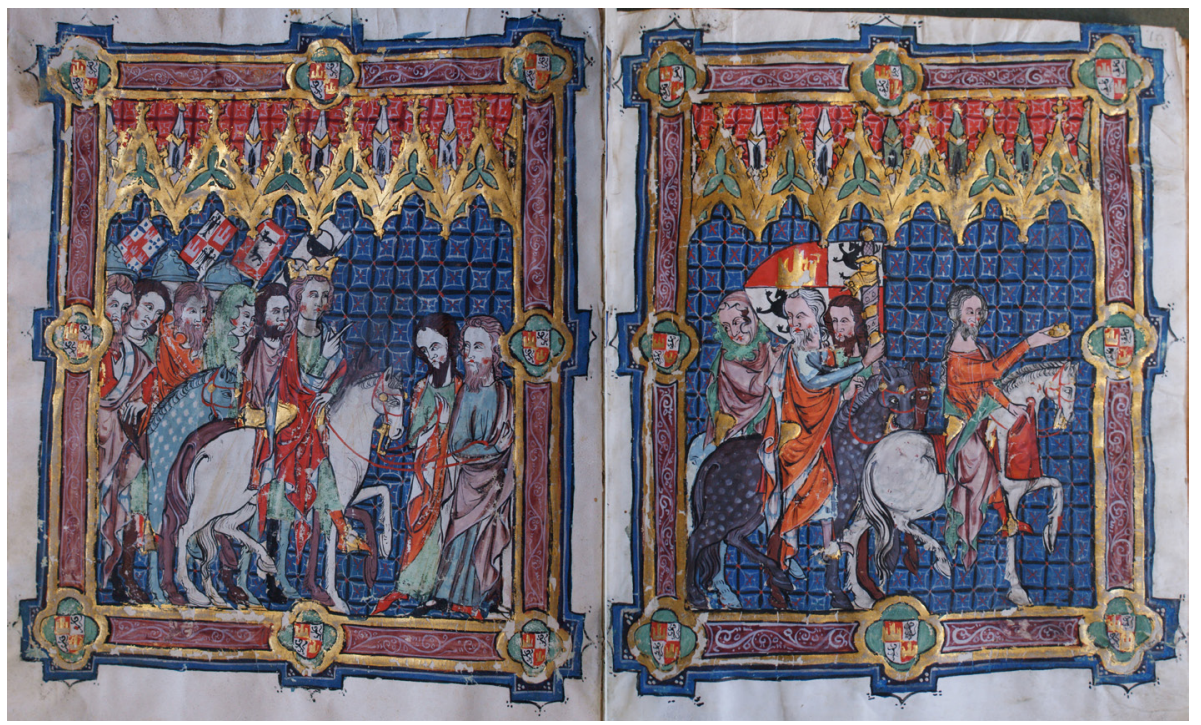

I. "Aquí es pintado e fi gurado cómo lieuan al Rey, et el que traye la espada, et el que esparge los dineros, e los que lieuan el cauallo por las riendas, et los obispos, et la clerecía”, Libro de la Coronación de los Reyes de Castilla, Biblioteca de El Escorial.

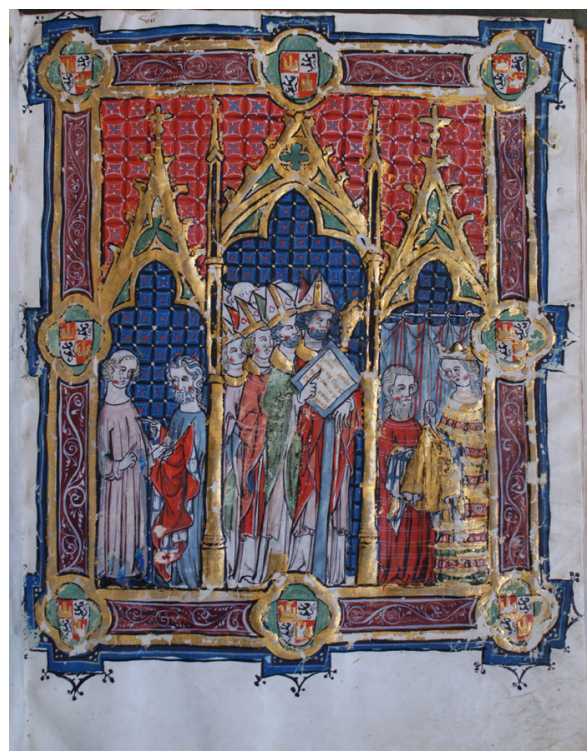

2. "Aquí es pintado e fi gurada la capiella do está el Rey con los obispos, e los panos de oro que toma e los que da, e los obispos e arçobispos e la clereçía e cómo cantan este responso Pater Amas me", Libro de la Coronación de los Reyes de Castilla, Biblioteca de El Escorial. 


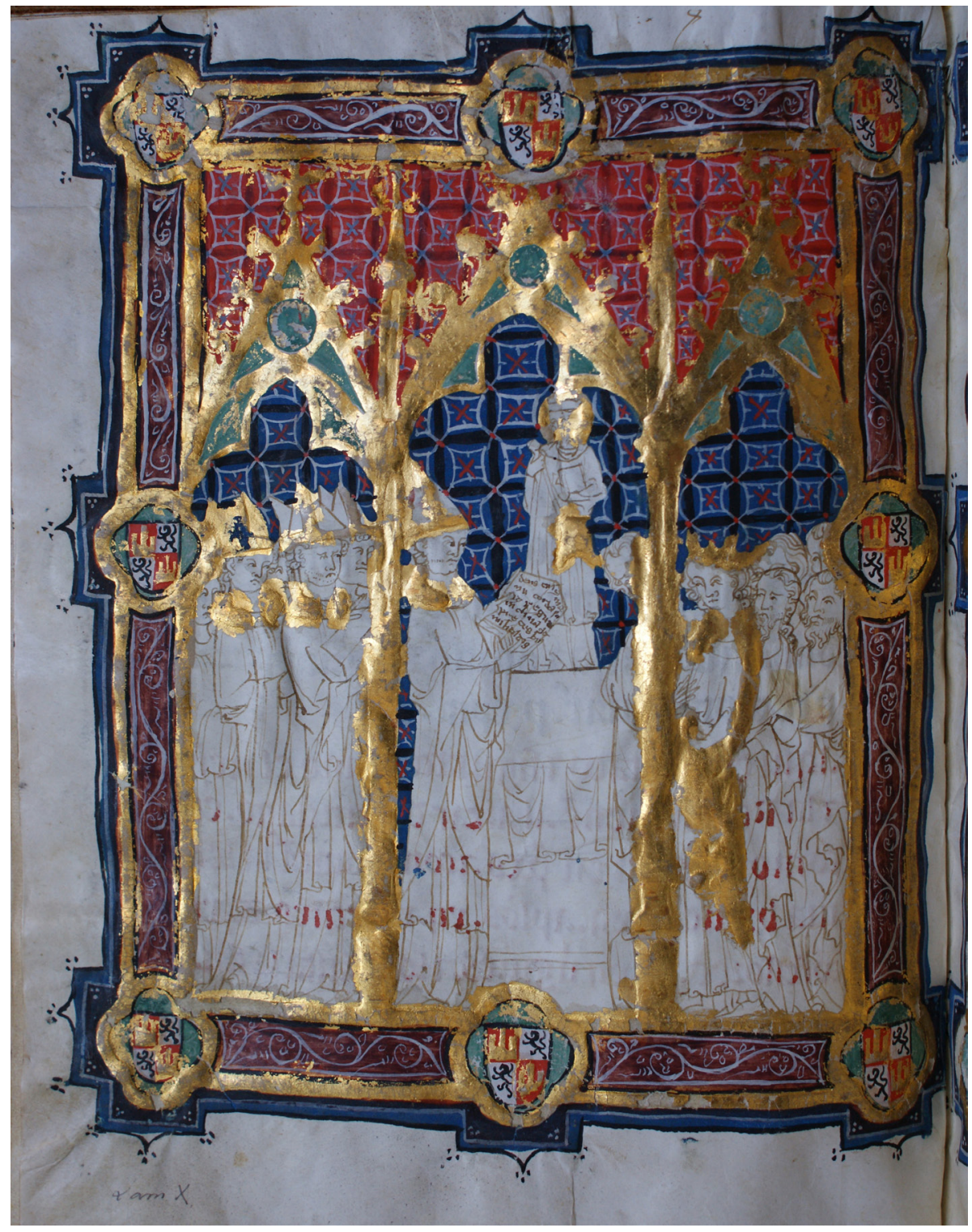

3. "Et acabadas las oraçiones lieuen al Rey sobraçado fasta el altar de Santiago", Libro de la Coronación de los Reyes de Castilla, Biblioteca de El Escorial. 


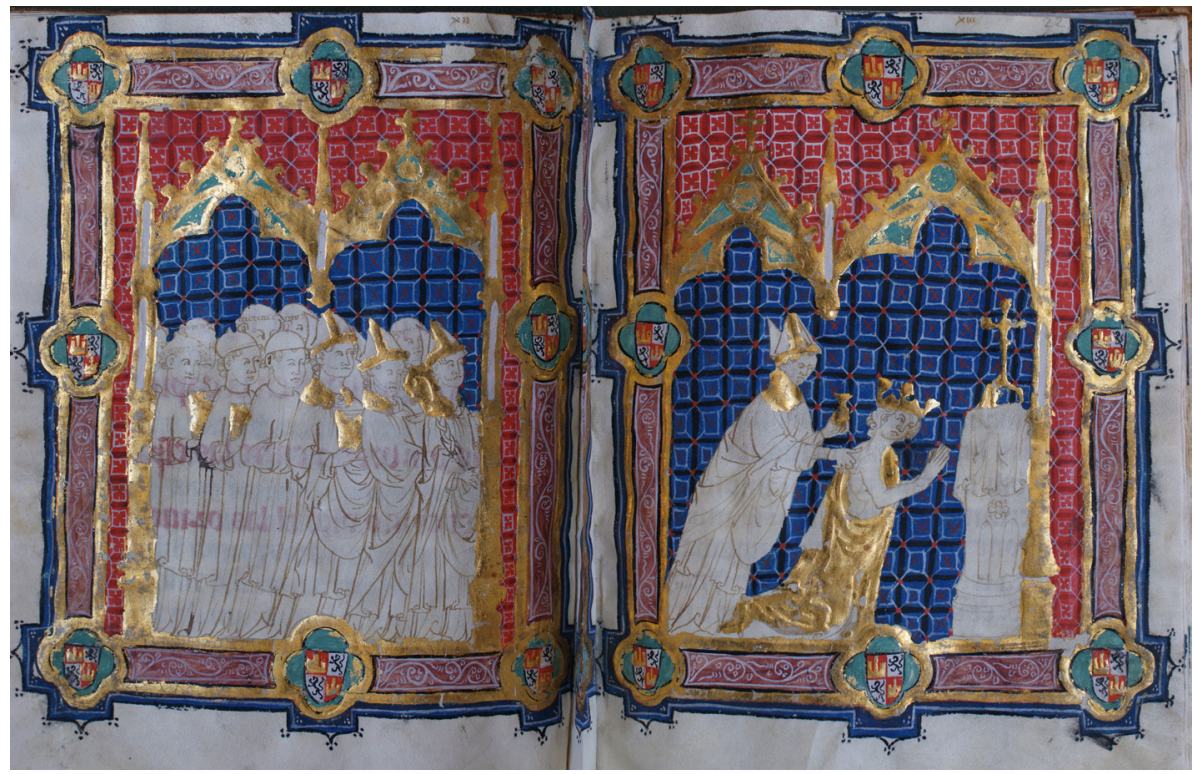

4. "Aquí es pintado e fi gurado cómo sagran al Rey en la capiella en los ombros e entre las espaldas, et cómo dice él las oraciones", Libro de la Coronación de los Reyes de Castilla, Biblioteca de El Escorial

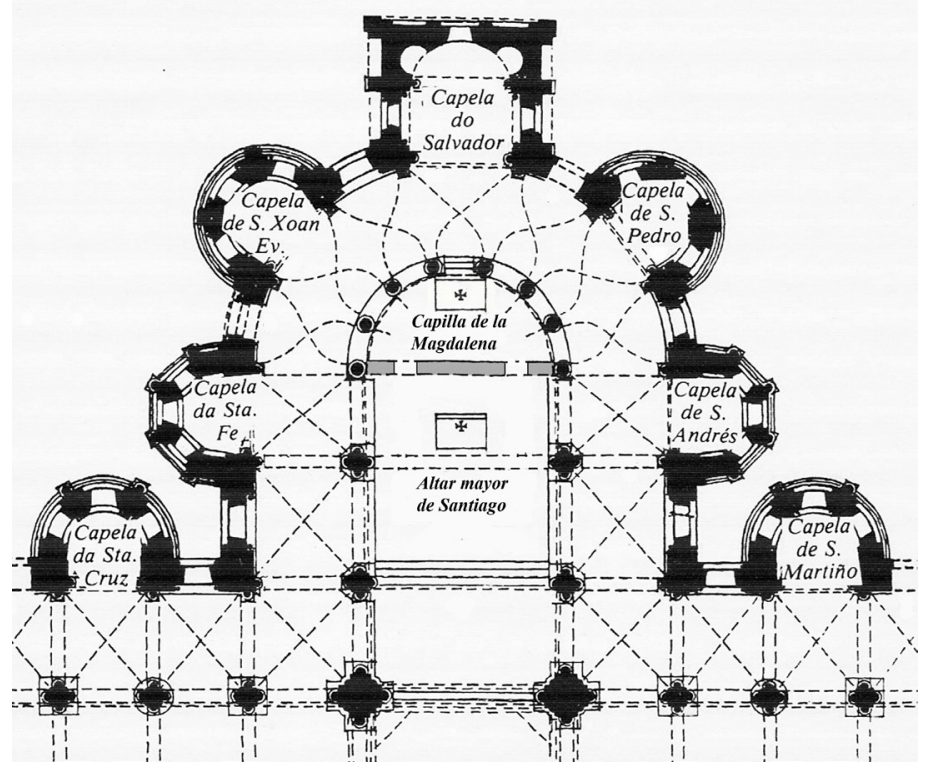

5. Catedral de Santiago. Localización de la retrocapilla de la Magdalena sobre la planta de Kenneth John Connant. 


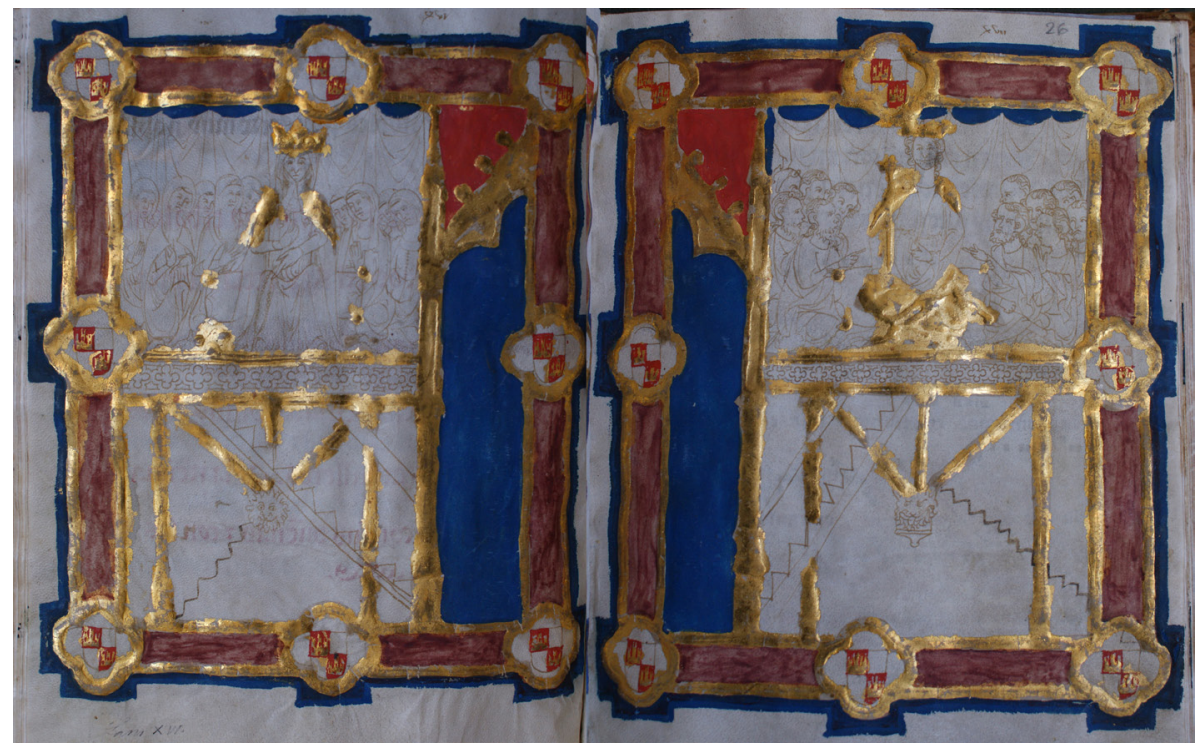

6. "Aquí es pintado e fi gurado el balcón, e los estrados del Rey e de la Reyna, e los destaios. Et cómo el Rey está assentado en su estrado con sus ricos omes e sus caballeros. Et la Reyna en el suyo con sus duennas e con sus doncellas", Libro de la Coronación de los Reyes de Castilla, Biblioteca de El Escorial.

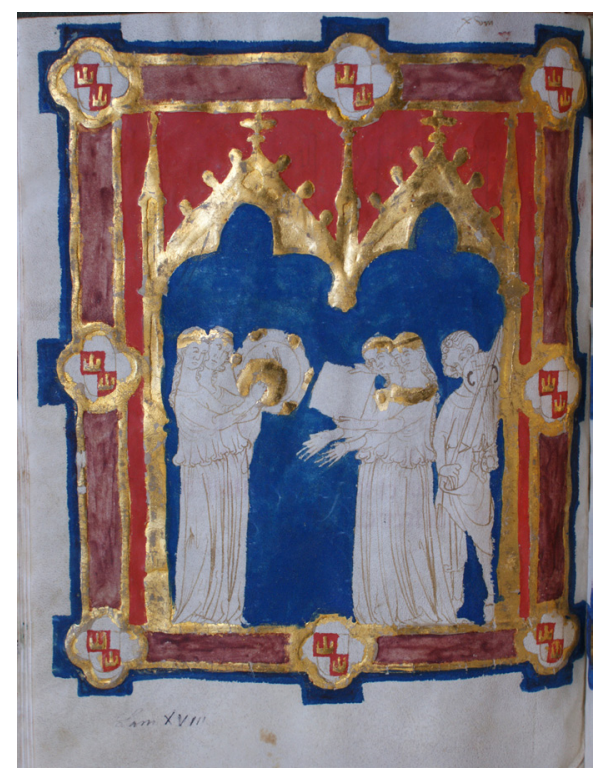

7. "Aquí es pintado e fi gurado cómo cantan las donçellas, e cómo trebeian los otros...", Libro de la Coronación de los Reyes de Castilla, Biblioteca de El Escorial. 


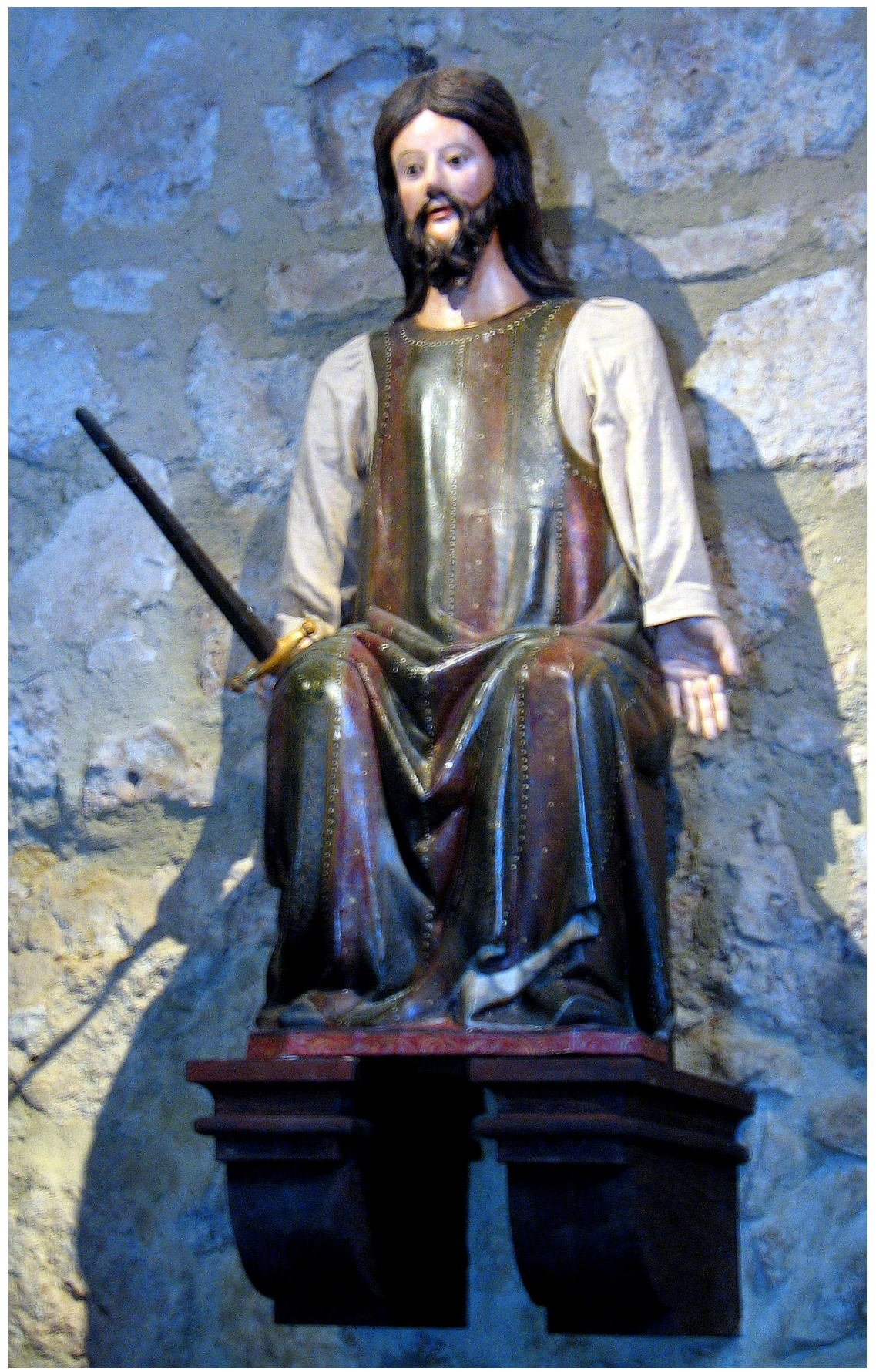

8. Santiago del espaldarazo. Monasterio de Santa María la Real de las Huelgas, Burgos. 